\title{
Ways of Improvement of Pedagogical Skill of Commanders
}

\author{
Abdurakhmanov Sherzod, \\ Safayev Husen \\ Teachers of military department of the Bukhara state university
}

\begin{abstract}
The significant role in formation and development of pedagogical skill of the sergeant (foreman) belongs to active inclusion in pedagogical activity of creativity. The efficiency of process of formation and development of pedagogical skill in many respects is defined also by work of the junior commander on self-improvement.

Keywords: pedagogical skill, training process, pedagogical observation, pedagogical insistence, commander, sergeant, psychology and pedagogical preparation.
\end{abstract}

For years of Independence in Uzbekistan the steady system of receiving education by the population which originates in preschool educational institutions and comes to the end at the level of academies is built. Military education is an important component of this harmonious system.

Military education makes the powerful contribution to implementation of the National program of training of the Republic of Uzbekistan. Adoption of such document once again demonstrates that training high quality is brought in our country to the level of state policy. And it bears fruits.

The task to realize a package of measures for further development of a uniform multilevel system of the training of junior commanders providing comprehensive updating of activity of schools of training of sergeants in full accordance with new modern requirements is set. Professionally prepared non-commissioned officer's structure not in words, and in practice has to become a support and a core of our army on which the moral and psychological and moral situation in each military collective in many respects depends.

Knowledge junior commanders of a pedagogical entity, contents and features of the organization of training activity and education of the military personnel helps them thoughtfully and to creatively solve problems of training and education of subordinates, to systematize and arrange the activity, to carry out it is pedagogically reasonable and assured to achieve goals.

Content of training of soldiers in parts and divisions is determined by curricula and programs. It is aimed at training of the military specialists meeting the requirements which are imposed by our state to defenders of the Fatherland. In this regard tasks are set for training activity: arm soldiers with the system of versatile knowledge, develop at them necessary skills and abilities, to create high moral and psychological and fighting qualities, to develop intellectual and physical forces, to prepare psychologically for military professional activity. In it the multifunctionality of this process is shown.

On the structure process of training represents the interconnected activity of training (commander) who various means of pedagogical influence and interaction has an impact on 
mentality of the military personnel and trained (soldiers) - they actively react to its influences, seizing at the same time certain knowledge, skills and abilities. Thus, both parties of process are indissoluble and active.

Training, stating a training material in the systematized look and showing the most expedient methods of practical work, psychologically trains trainees for perception of the studied material, develops at them cognitive and professional interest to a subject; improves abilities and ability to independently acquire knowledge, to seize professional skill; analyzes work of trainees and controls assimilation of knowledge, skills and abilities. At the solution of this complex of the interconnected tasks training acts first of all as the organizer of educational activity. At the same time it performs also function of the tutor.

The significant role in results of training and education is played by pedagogical skill of the sergeant (foreman) which acts as a rod component of pedagogical culture of training. It in many respects characterizes the professional and moral level of the sergeant (foreman).

The pedagogical skill represents the system of knowledge, skills and abilities, ways of thinking, emotional means of expressiveness which in interaction allows it to solve teaching and educational problems with advanced pedagogical personal qualities of the teacher successfully.

In the structural relation join in pedagogical skill: pedagogical equipment, erudition, observation, imagination, thinking, insistence, step and also standard of speech.

The pedagogical technology is a complex of various skills and abilities, receptions and means by means of which the sergeant (foreman) reaches efficiency of application of methods of pedagogical impact on certain trainees and on collective in general. In the most general view the pedagogical equipment includes:

a) skills and abilities in the organization of studies;

b) methods of expressive display of the relation, feelings to these or those actions of trainees, technology of the speech;

c) "technology" of studying and accounting of specific features of the personality, psychology and pedagogical features of collectives;

d) skills and abilities in mastering technical means of training and other means of presentation;

e) pedagogical account and control of education and good training of the military personnel.

The pedagogical erudition of the sergeant (foreman) is shown in free possession of fundamentals of psychology and pedagogics, ability to carry out the psychology and pedagogical analysis of offense, the fact, "phenomenon" to define concrete measures of pedagogical influence, effective forms, methods. means of teaching and educational work.

The pedagogical observation of the sergeant (foreman) includes the following abilities: to watch systematically behavior and activity of trainees; to determine by insignificant signs of feature of interior, his experience and mood, to notice all happening changes.

The pedagogical imagination assumes: 
a) ability of the junior commander to mentally present inner world of the military personnel;

b) ability correctly, clearly and lively to define the possible factors affecting behavior of the trainee and on his attitude towards surrounding reality;

c) ability to expect various options of behavior of trainees in this or that situation, under the influence of this or that factor, means;

d) ability to present and plan the main actions, the actions for training, education or reeducation of subordinates.

Pedagogical thinking of the sergeant (foreman) is characterized by his ability:

a) to quickly analyze the behavior, behavior of trainees, their relation to work, to allocate basic elements and signs in behavior of each trainee and collective in general;

b) to synthesize, to mentally establish connection, to unite the separate moments in the activity and activity of trainees, in their relation to educational process;

c) to compare separate elements in behavior of the military personnel, to define similarity and differences in each pedagogical situation;

d) to draw the correct conclusions from the activity and to give an objective assessment to actions, knowledge of trainees.

The following features of the speech have to be inherent in the sergeant (foreman): high culture; pithiness and harmonious development in all its types; highly moral relation to a word - fidelity to this promise, responsibility of statements; possession of speech emotional means of expression (intonation, speed, expressiveness, timbre, mimicry, gesticulation, etc.).

Pedagogical insistence as the many-sided, generalized quality of the sergeant (foreman) is shown first of all in his attitude towards surrounding people and also towards itself. Using insistence as an educational tool, it is necessary to remember that it has to proceed from the interests of business, to be a constant, to extend to all members of collective equally and to be combined with respect of personal dignity of trainees, with insistence to itself.

The pedagogical step is the difficult professional quality of the sergeant (foreman) which is characterized by pedagogically expedient measure of his relations with trainees and impacts on them in a concrete situation. The pedagogical step is possible only at the most sincere respect of subordinates. An important condition of its manifestation is the ability to be self-controlled and to observe pedagogically expedient measure in application of teaching and educational influence.

The considered qualities in their unity and interconditionality are that basis on which the skill of the sergeant (foreman) as the teacher and the tutor of the military personnel is formed and improved.

Thus, during formation and development of pedagogical skill the sergeant (foreman) needs to develop at himself certain qualities, knowledge, skills and abilities, to improve those parties of the personality which play a crucial role in growth of skill of the teacher. Along with development of personal qualities of the teacher it is necessary to improve the psychology and 
pedagogical preparation, to join actively in daily pedagogical activity, work on improvement of the main components of pedagogical skill.

\section{References}

1. Yenikeev M.I. Obshhaja i social'naja psihologija. [General and social psychology.] - M.: TK Velbi, Prospect, 2007.

2. Karayani A. G. Prikladnaja voennaja psihologija : uchebno-metodicheskoe posobie : (uchebnoe posobie dlja kursantov i slush. vyssh. voen.-ucheb. zavedenij) [Applied military psychology: educational and methodical manual: (manual for cadets)] / A.G. Karayani, I.V. Syromyatnikov. - SPb. [etc.]: St. Petersburg, 2006.

3. Yurchenko Yu. Puti $i$ sposoby povyshenija kachestva vospitatel'nogo processa $v$ podrazdelenii [Ways and methods of improvement of quality of educational process in division] // Oriyentir. - 2006. - No. 7.

\section{Translation of the References to the Author's Language}

\section{Литература}

1. Еникеев М.И. Общая и социальная психология. - М.: ТК Велби, Проспект, 2007.

2. Караяни А. Г. Прикладная военная психология : учебно-методическое пособие: [учебное пособие для курсантов и слуш. высш. воен.-учеб. заведений] / А. Г. Караяни, И. В. Сыромятников .-СПб. [и др.] : Питер, 2006.

3. Юрченко Ю. Пути и способы повышения качества воспитательного процесса в подразделении // Ориентир. - 2006. - № 7. 